\title{
Distribution of Sandflies (Diptera:Psychodidae) on Tree-trunks in a Non-flooded Area of the Ducke Forest Reserve, Manaus, AM, Brazil MRS Cabanillas ${ }^{+}$, EG Castellón
}

Laborátorio de Entomologia Médica, Instituto Nacional de Pesquisas da Amazônia, Caixa Postal 478, 69083-000 Manaus, AM, Brasil

Sandflies were collected in the base of tree-trunks in the seasons of high and least rainfall in the Ducke Forest Reserve, near Manaus in the State of Amazonas. Lutzomyia umbratilis was the most abundant sandfly species. Caryocar villosum, Chrysophyllum amazonicum, Dinizia excelsa, Eschweilera atropetiolata and Parkia multijuga were the tree species on which most sandflies were collected and relative abundance were related to trunk characteristics. Seasonal patterns of sandfly distribution in the forest were observed.

Key words: tree - sandflies - Ducke Reserve - Amazonas - Brazil

Tropical forests are famous for being the most species rich ecosystems on earth (Gentry 1992). In some of these forests, such as in the Brazilian Central Amazon, the phlebotomine sandflies show a high diversity index $\left(a=10.0^{+} /-1\right.$, Barrett et al. 1996) and an adaptation to diverse biotopes (Christensen et al. 1983).

Shaw and Lainson (1972) and Ready et al. (1983, 1984) studied the association of some sandfly species with phyto-ecological and phytotopographical features of forested areas in the Brazilian Amazon: Lutzomyia flaviscutellata occurred in non-climax primary and secondary forests and Lu. wellcomei in the higher topographical elevation forest.

Lu. umbratilis populations, vectors of Leishmania (Viannia) guyanensis an aetiological agent of "pian-bois", are mostly distributed in higher topographical elevation areas, and may be seen resting on the bases of tall trees (girth $>1 \mathrm{~m}$ and furrowed bark) throughout the day (Ready et al. 1983, 1985, Barrett et al. 1991).

The bases of tall trees have been considered as a link between the canopy (where Le. (V.) guyanensis cycle develops) and the forest floor where human infection by $L u$. umbratilis occurs (Geoffroy et al. 1986). Studies of these habitats

\footnotetext{
${ }^{+}$Corresponding author. Fax: +55-92-643.3233. E-mail: marcos@inpa.gov.br Received 3 July 1998 Accepted 10 February 1999
}

with respect to sandfly populations are of great importance in the planning of control strategies in non-flooded primary rain forested areas, where agro-forestry, road building and urban area enlargement projects, are underway.

There is a need to investigate the relationship between sandflies and the morphological characteristics of trees that might be favouring vector species of sandflies, in particular the sandfly distribution and interspecific competition at a height ranging from 0 to $2 \mathrm{~m}$ above ground level in a nonflooded primary forest area. This is the objective of the present work.

Experimental area - The study area, Ducke Forest Reserve (DRF), is located in the Brazilian Central Amazon, between the geographic coordinates $\left(02^{\circ} 55^{\prime}\right.$ to $03^{\circ} 00^{\prime} \mathrm{S}$ and $59^{\circ} 53^{\prime}$ to $\left.59^{\circ} 59^{\prime} \mathrm{W}\right)$. It encompasses an area of 10,072 ha, and is approximately 80 to $100 \mathrm{~m}$ above sea level.

Further geomorphologic, vegetational and climatic characteristic are described by Penny and Arias (1982), Franken et al. (1992) and Rodriguez (1995).

\section{MATERIALS AND METHODS}

Sandflies were collected during high and low rainfall periods (February to April and July to September 1993). The sampling was carried out in the first and third week of each study month, three days a week, from 07:00 to 15:00 hr.

The study area was subdivided in two subareas of $5,000 \mathrm{~m}^{2}$ each. Sandflies were collected by suction devices and by active searching on 36 treetrunks, belonging to 21 species (Table I), with a CDC modified light trap (Cabanillas et al. 1995) and collecting with $10 \times 1.5 \mathrm{~mm}$ glass tubes. 
TABLE I

List of the tree species (with code of identification) on which the sandflies were collected

\begin{tabular}{|c|c|c|}
\hline Scientific name & Code & Family \\
\hline Anacardium spruceanum & An. & Anacardiaceae \\
\hline Aspidosperma odiscolor & As. & Apocynaceae \\
\hline Chrysophyllum amazonicum & Ch. & Apocynaceae \\
\hline Geissospermum sp. & Ge. & Apocynaceae \\
\hline Ephedranthus amazonicus & Ep. & Anonaceae \\
\hline Protium sp. & $\mathrm{P} 1$ & Burseraceae \\
\hline Caryocar villosum & Ca. & Caryocaraceae \\
\hline Dinizia excelsa & Di. & Mimosaceae \\
\hline Inga $\mathrm{sp}$. & In. & Mimosaceae \\
\hline Parkia multijuga & $\mathrm{P} 2$ & Mimosaceae \\
\hline Piptadenia suaveolens & P3 & Mimosaceae \\
\hline Pithecolobium racemosum & $\mathrm{P} 4$ & Mimosaceae \\
\hline Brosimum parinaroides & $\mathrm{Br}$. & Moraceae \\
\hline Bochoa sp. & Bo. & Cesalpinaceae \\
\hline Swartzia schomburgkii & Sw. & Cesalpinaceae \\
\hline Couratari longipedicelata & Co. & Lecythidaceae \\
\hline Eschweilera atropetiolata & Es. & Lecythidaceae \\
\hline Sloanea brachytepala & S1. & Elaeocarpaceae \\
\hline Vantanea sp. & Va. & Humiriaceae \\
\hline Sacoglottis matogrossensis & Sa. & Humiriaceae \\
\hline Palicourea grandifolia & $\mathrm{Pa}$. & Rubiaceae \\
\hline
\end{tabular}

The peculiarities of each tree trunk were noted. For example, bark type (smooth or furrowed), development of buttress roots and diameter of core trunk, measured immediately above the uppermost junction of the highest buttress with the trunk (Smith 1972).

Collections with a suction trap (a CDC modified light trap) - Sampling was carried out with a suction trap on all tree-trunks in each subarea, from ground level to $2 \mathrm{~m}$ above ground level. The aim was to spend no longer than 15 min sampling each tree, in order to get a standard collection time.

Active searching of sandflies - The sandflies were searched for on each tree, at the same times mentioned above for every collecting day, using a flashlight for this purpose. Flies were collected with a glass tube (two to three specimens in each tube) which was closed with cotton.

For each tree, sampling was carried out during a 15 min period, regardless of the presence or absence of sandflies, in order to establish a standard collecting period. So as not to use both collection techniques on the same tree, each technique was carried out in one subarea, which were sampled simultaneously.

Statistical analysis - The association between collection technique, abundance of sandflies and tree trunk diameter were analyzed by Spearman Rank Correlation Test (Zar 1984). The association between the former two variables with morphological characteristics of tree trunk employed a biserial point correlation test. Morphological characteristics of tree trunks were coded in relation to presence/absence.

\section{RESULTS}

A total of 3,975 sandflies was collected, belonging to 20 species. Ninety one point six percent were collected by active searching (see Materials and Methods) and only $8.9 \%$ with the suction trap. Quantitative differences due to collecting techniques and seasonality were remarkable (Table IV). However, since the main objective was the relationship between tree species and sandflies, our analyses were carried out on the total number of individuals captured with both techniques. The overall ratio of males to females was $1.8(64.3 \%$ males and $35.8 \%$ females) and did not vary much for the same tree species or by seasons.

Lu. umbratilis Fraiha \& Ward was the most frequent and abundant (85.3\%) sandfly species on all sampled trees, but showed quantitative variations from tree to tree (Table II) and from season to season (Fig. 1). Lu. dendrophila Mangabeira and Lu. shannoni Dyar were also collected during the two seasons but in smaller quantities.

Lu. umbratilis was collected on 18 of the 22 tree species studied. However, $75 \%$ of all the specimens were encountered on only 12 tree species. A minimum frequency of $66.2 \%$ was founded on Piptadenia suaveolens and a maximum of $100 \%$ on Geissospermun sp. and Pithecolobium 
TABLE II

Relative frequency of Lutzomyia species on each tree species sampled in the Ducke Forest Reserve

\begin{tabular}{|c|c|c|c|c|c|c|c|c|c|c|}
\hline Scientific name & DAV & DEN & FLA & ROR & SCA & SHA & UMB & Others & $(\%)$ & IND \\
\hline Anacardium spruceanum & 0.0 & 1.8 & 0.0 & 0.0 & 0.0 & 9.1 & 89.1 & 0.0 & 100 & 55 \\
\hline Aspidosperma odiscolor & 0.0 & 2.1 & 0.0 & 1.0 & 1.0 & 6.2 & 85.6 & 4.1 & 100 & 97 \\
\hline Bochoa sp. & 0.0 & 4.7 & 0.0 & 3.1 & 6.3 & 0.0 & 85.9 & 0.0 & 100 & 64 \\
\hline Caryocar villosum & 0.0 & 5.6 & 0.0 & 0.9 & 2.2 & 2.6 & 86.6 & 2.1 & 100 & 231 \\
\hline Chrysophyllum amazonicum & 0.0 & 4.7 & 0.4 & 0.4 & 1.3 & 2.6 & 89.8 & 0.9 & 100 & 235 \\
\hline Couratari longipedicelata & 0.3 & 6.3 & 0.0 & 0.9 & 1.7 & 5.1 & 84.3 & 1.4 & 100 & 350 \\
\hline Dinizia excelsa & 0.1 & 7.4 & 0.1 & 10 & 1.3 & 6.7 & 82.4 & 0.8 & 100 & 675 \\
\hline Ephedranthus amazonicus & 0.0 & 2.6 & 0.2 & 0.9 & 2.6 & 3.7 & 89.1 & 0.9 & 100 & 430 \\
\hline Eschweilera atropetiolata & 5.5 & 2.0 & 0.0 & 0.4 & 0.4 & 2.4 & 88.2 & 1.2 & 100 & 254 \\
\hline Geissospermum sp. & 0.0 & 0.0 & 0.0 & 0.0 & 0.0 & 0.0 & 100 & 0.0 & 100 & 16 \\
\hline Palicourea grandifolia & 0.0 & 6.3 & 0.0 & 6.3 & 0.0 & 12.5 & 68.8 & 6.3 & 100 & 16 \\
\hline Parkia multijuga & 0.3 & 11.0 & 0.0 & 0.0 & 2.1 & 5.4 & 80.7 & 0.5 & 100 & 373 \\
\hline Piptadenia suaveolens & 0.0 & 23.1 & 0.0 & 0.0 & 3.1 & 6.2 & 66.2 & 1.5 & 100 & 65 \\
\hline Pithecolobium racemosum & 0.0 & 0.0 & 0.0 & 0.0 & 0.0 & 0.0 & 100 & 0.0 & 100 & 37 \\
\hline Sacoglottis matogrossensis & 0.0 & 0.0 & 0.0 & 0.0 & 0.0 & 0.0 & 97.1 & 2.9 & 100 & 34 \\
\hline Sloanea brachytepala & 1.0 & 7.4 & 0.5 & 1.0 & 2.9 & 7.8 & 78.4 & 1.0 & 100 & 204 \\
\hline Swartzia schomburgkii & 0.0 & 6.3 & 0.0 & 0.0 & 1.6 & 1.6 & 90.6 & 0.0 & 100 & 64 \\
\hline Vantanea sp. & 1.0 & 5.1 & 0.0 & 4.0 & 2.0 & 2.0 & 85.9 & 0.0 & 100 & 99 \\
\hline
\end{tabular}

DAV: Lu. davisi; DEN: Lu. dendrophila; FLA: Lu. flaviscutellata; ROR: Lu. rorotaensis; SCA: Lu. scaffi; SHA: Lu. shannoni; UMB: Lu. umbratilis, IND: no. of individuals.
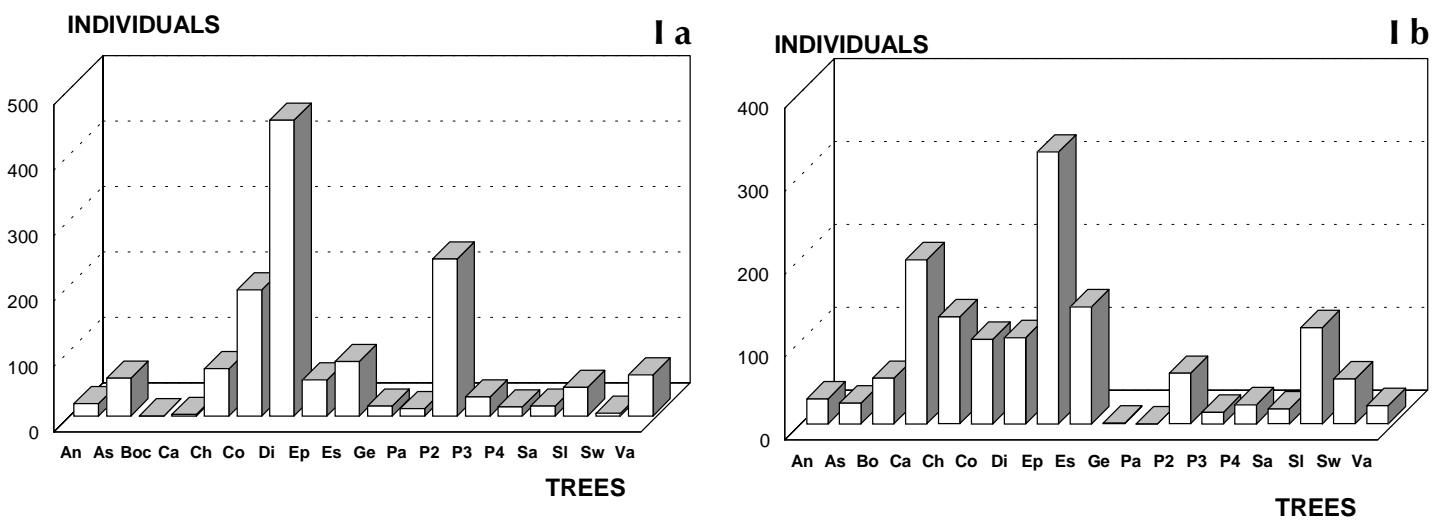

INDIVIDUALS

II $\mathbf{a}$

INDIVIDUALS

II b
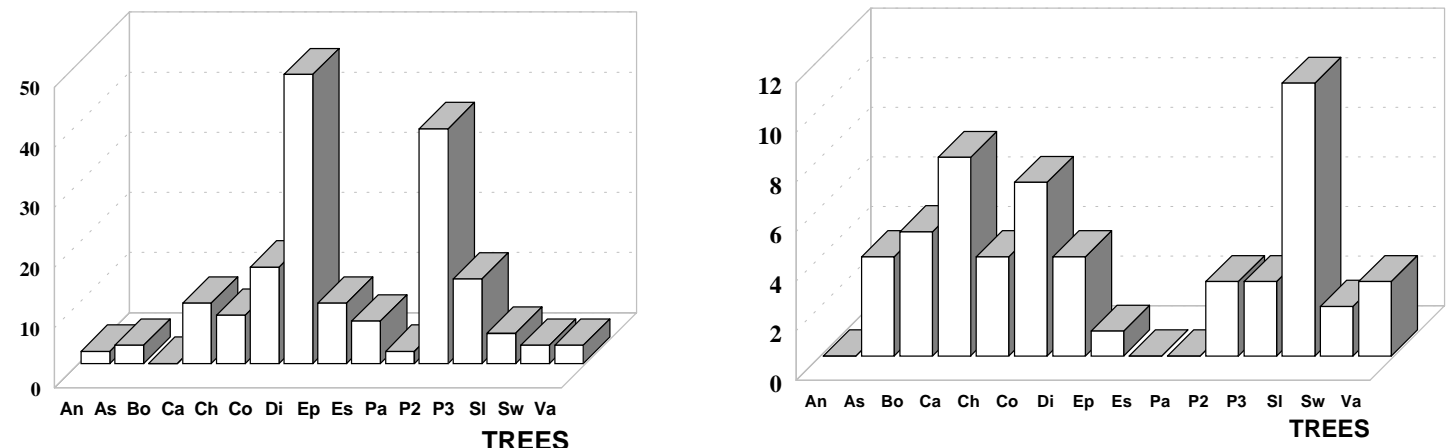

Fig. 1: distribution of Lutzomyia umbratilis ${ }^{(\mathrm{I})}$ and Lu. dendrophila ${ }^{(\mathrm{II})}$ on tree species in the high (a) and lower (b) rainfall seasons in the Ducke Reserve Forest. An: Anacardium spruceanum; As: Aspidosperma odiscolor; Boc: Bochoa sp.; Ca: Caryocar villosum; Ch: Chrysophyllum amazonicum; Co: Couratari longipedicelata; Di: Dinizia excelsa; Ep: Ephedranthus amazonicus; Es: Eschweilera atropetiolata; Ge: Geissospermum sp.; P2: Parkia multijuga; P3: Piptadenia suaveolens; P4: Pithecolobium racemosum; Sa: Sacoglottis matogrossensis; S1: Sloanea brachytepala; Sw: Swartzia schomburgkii; Va: Vantanea sp. 
TABLE III

Relative frequency of Lutzomyia species sampled on different tree species in the Ducke Forest Reserve

\begin{tabular}{lrrrrrrrr}
\hline Scientific name & DAV & DEN & FLA & ROR & SCA & SHA & UMB & Others \\
\hline Anacardium spruceanum & 0.0 & 0.5 & 0.0 & 0.0 & 0.0 & 3.3 & 1.8 & 0.0 \\
Aspidosperma odiscolor & 0.0 & 1.0 & 0.0 & 3.6 & 1.7 & 3.9 & 3.0 & 11.1 \\
Bochoa sp. & 0.0 & 1.5 & 0.0 & 7.1 & 6.8 & 0.0 & 2.0 & 0.0 \\
Caryocar villosum & 0.0 & 6.5 & 0.0 & 7.1 & 8.5 & 3.9 & 7.1 & 13.9 \\
Chrysophyllum amazonicum & 0.0 & 5.5 & 25.0 & 3.6 & 5.1 & 3.9 & 7.5 & 5.6 \\
Couratari longipedicelata & 5.0 & 11.1 & 0.0 & 10.7 & 10.2 & 11.8 & 10.5 & 13.9 \\
Dinizia excelsa & 5.0 & 25.1 & 25.0 & 25.0 & 15.3 & 29.4 & 19.9 & 16.7 \\
Ephedranthus amazonicus & 0.0 & 5.5 & 25.0 & 14.3 & 18.6 & 10.5 & 13.7 & 11.1 \\
Eschweilera atropetiolata & 70.0 & 2.5 & 0.0 & 3.6 & 1.7 & 3.9 & 8.0 & 8.3 \\
Geissospermum sp. & 0.0 & 0.0. & 0.0 & 0.0 & 0.0 & 0.0 & 0.6 & 0.0 \\
Palicourea grandifolia & 0.0 & 0.5 & 0.0 & 3.6 & 0.0 & 1.3 & 0.4 & 2.8 \\
Parkia multijuga & 5.0 & 20.6 & 0.0 & 0.0 & 13.6 & 13.1 & 10.8 & 5.6 \\
Piptadenia suaveolens & 0.0 & 7.5 & 0.0 & 0.0 & 3.4 & 2.6 & 1.5 & 2.8 \\
Pithecolobium racemosum & 0.0 & 0.0 & 0.0 & 0.0 & 0.0 & 0.0 & 1.3 & 0.0 \\
Sacoglottis matogrossensis & 0.0 & 0.0 & 0.0 & 0.0 & 0.0 & 0.0 & 1.2 & 2.8 \\
Sloanea brachytepala & 10.0 & 7.5 & 25.0 & 7.1 & 10.2 & 10.5 & 5.7 & 5.6 \\
Swartzia schomburgkii & 0.0 & 2.0 & 0.0 & 0.0 & 1.7 & 0.7 & 2.1 & 0.0 \\
Vantanea sp. & 5.0 & 2.5 & 0.0 & 14.3 & 3.4 & 1.3 & 3.0 & 0.0 \\
(\%) & 100 & 100 & 100 & 100 & 100 & 100 & 100 & 100 \\
\hline Total & 20 & 199 & 4 & 28 & 59 & 153 & 2800 & 36
\end{tabular}

DAV: Lu. davisi; DEN: Lu. dendrophila; FLA: Lu. flaviscutellata; ROR: Lu. rorotaensis; SCA: Lu. scaffi; SHA: Lu. shannoni; UMB: Lu. umbratilis; IND: no. of individuals.

racemosum (Table II). However, if we analyze the occurrence of $L u$. umbratilis on the total number of inspected trees, we find that only $0.6 \%$ and $1.3 \%$ of the flies were collected on the latter two tree species (Table III).

Lu. dendrophila and Lu. shannoni apparently are associated with specific tree species, at least up to a height of $2 \mathrm{~m}$ above ground level (Figs 1, 2). Few specimens of $L u$. dendrophila were caught on Anacardium spruceanum, Aspidosperma odiscolor and Eschweilera atropetiolata. Few specimens of Lu. shannoni were collected on
Caryocar villosum, Chrysophyllum amazonicum, E. atropetiolata, Swartzia schomburgkii and Vantanea sp. Both sandfly species occurred on the same trees, except for Bochoa sp. (Fig. 2). The relationship of Lu. umbratilis and Lu. dendrophila represented at least $23 \%$ of the total sandflies collected, on all inspected tree, whereas the relationship of Lu. umbratilis with Lu. shannoni represented only $6.2 \%$.

C. villosum, C. amazonicum, Dinizia excelsa, Ephedranthus amazonicus, E. atropetiolata, Couratari longipedicelata and Parkia multijuga
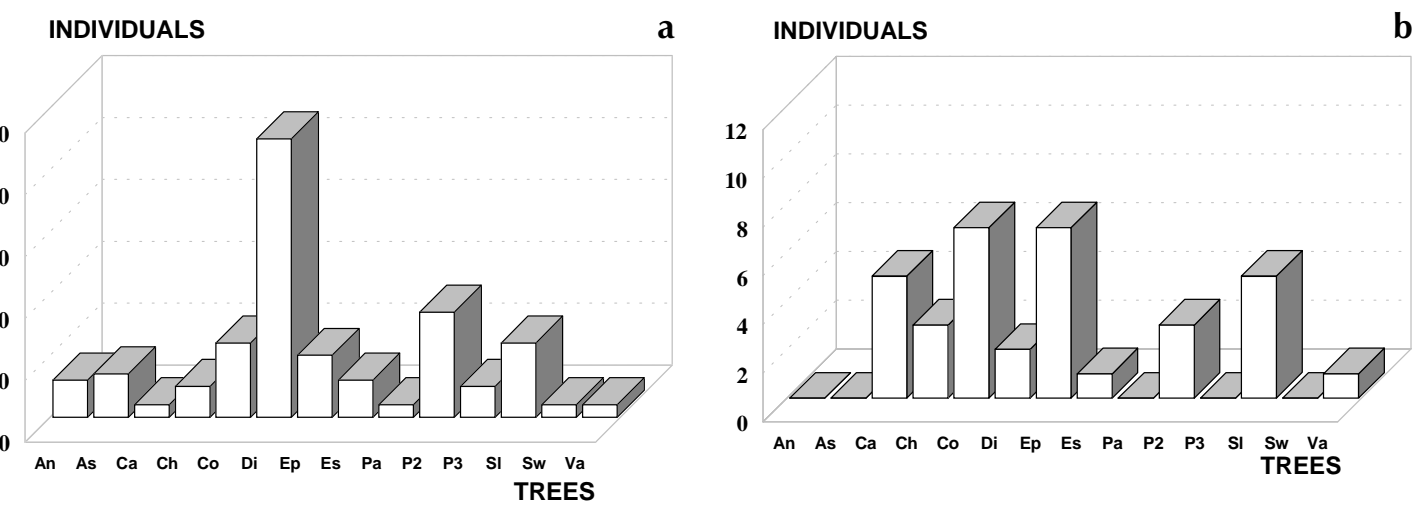

Fig. 2: distribution of Lutzomyia shannoni on tree species in the high (a) and lower (b) rainfall seasons in the Ducke Reserve Forest. An: Anacardium spruceanum; As: Aspidosperma odiscolor; Ca: Caryocar villosum; Ch: Chrysophyllum amazonicum; Co: Couratari longipedicelata; Di: Dinizia excelsa; Ep: Ephedranthus amazonicus; Es: Eschweilera atropetiolata; Pa: Palicourea grandifolia; P2: Parkia multijuga; P3: Piptadenia suaveolens; S1: Sloanea brachytepala; Sw: Swartzia schomburgkii; Va: Vantanea sp. 
TABLE IV

Abundance of sandflies according to collection technique and season in a plateau area of the Ducke Forest Reserve

\begin{tabular}{|c|c|c|c|c|c|c|}
\hline \multirow[t]{2}{*}{ Tree species } & \multicolumn{2}{|c|}{ Active search } & \multicolumn{2}{|c|}{ Suction } & \multicolumn{2}{|c|}{ Total } \\
\hline & Rainy & Drier & Rainy & Drier & Rainy & Drier \\
\hline Anacardium spruceanum & 29 & 30 & 0 & 0 & 29 & 30 \\
\hline Aspidosperma odiscolor & 88 & 112 & 5 & 0 & 93 & 112 \\
\hline Bochoa sp. & 0 & 53 & 0 & 7 & 0 & 60 \\
\hline Brosimum parinaroides & 0 & 1 & 0 & 0 & 0 & 1 \\
\hline Caryocar villosum & 415 & 196 & 67 & 16 & 482 & 212 \\
\hline Chrysophyllum amazonicum & 60 & 117 & 13 & 12 & 73 & 129 \\
\hline Couratari longipedicelata & 173 & 93 & 20 & 9 & 193 & 102 \\
\hline Dinizia excelsa & 476 & 485 & 33 & 29 & 509 & 514 \\
\hline Ephedranthus amazonicus & 45 & 298 & 10 & 30 & 55 & 328 \\
\hline Eschweilera atropetiolata & 73 & 175 & 10 & 16 & 83 & 191 \\
\hline Geissospermum sp. & 15 & 1 & 0 & 0 & 15 & 1 \\
\hline Inga sp. & 0 & 0 & 0 & 0 & 0 & 0 \\
\hline Palicourea grandifolia & 11 & 0 & 0 & 0 & 11 & 0 \\
\hline Parkia multijuga & 222 & 56 & 25 & 5 & 247 & 61 \\
\hline Piptadenia suaveolens & 29 & 9 & 0 & 5 & 29 & 14 \\
\hline Pithecolobium racemosum & 14 & 23 & 0 & 0 & 14 & 23 \\
\hline Protium sp. & 0 & 24 & 0 & 5 & 0 & 29 \\
\hline Sacogloyyis matogrossensis & 15 & 18 & 0 & 0 & 15 & 18 \\
\hline Sloanea brachytepala & 25 & 108 & 12 & 14 & 37 & 122 \\
\hline Swartzia schomburgkii & 4 & 54 & 0 & 0 & 4 & 54 \\
\hline Trachiniquia sp. & 0 & 0 & 0 & 0 & 0 & 0 \\
\hline Vantanea sp. & 51 & 22 & 12 & 0 & 63 & 22 \\
\hline Total & 1745 & 1875 & 207 & 148 & 1952 & 2023 \\
\hline
\end{tabular}

sheltered the largest number of sandfly species and individuals throughout the study period, whereas Geissospermum sp. and P. racemosum were frequented only by $L u$. umbratilis. Palicourea grandifolia and Bochoa sp. were frequented by $L u$. umbratilis, Lu. dendrophila, Lu. shannoni, Lu. scaffi and Lu. rorotaensis (Table II, Figs 1,2).

Seasonality - The sandfly distribution by tree species, at a height from 0 to $2 \mathrm{~m}$ above ground level, seemed to follow a seasonal pattern. $D$. excelsa, P. multijuga and C. longipedicelata presented the largest number of sandflies in the high rainy season; whereas $C$. longipedicelata, $C$. amazonicum, E. amazonicus, E. atropetiolata and Sloanea brachytepala were frequented more in the low rainy season.

Lu. umbratilis followed the pattern of the above cited species in the rainy season, but it frequented E. amazonicus, E. atropetiolata and C. villosum in larger numbers in the less rainy season. However, individuals of $L u$. umbratilis were not frequent on Bochoa sp., C. villosum and S. schomburgkii in the rainy season and Geissospermum sp. and $P$. grandifolia in the less rainy season (Fig. 1, Ia, Ib).

$L u$. dendrophila showed the same behaviour as Lu. umbratilis in the rainy season. However, it was more frequent on $C$. villosum, $C$. longipedicelata and $S$. brachytepala in the less rainy season. Males outnumbered females in both seasons, especially in the less rainy season. Individuals of Lu. dendrophila were not collected on Bochoa sp. in the rainy season and on $A$. spruceanum, A. odiscolor, E. atropetiolata and $P$. grandifolia in the less rainy season (Fig. 1, IIa, IIb).

Lu. shannoni showed a distribution pattern like that of Lu. umbratilis and Lu. dendrophila in the rainy season. However, it was collected in larger numbers on $C$. villosum, $C$. longipedicelata, $E$. amazonicus and S. brachytepala in the season of less rainfall, making a possible alternative peak at this time of year for the sandfly species cited above.

In the present study, tree trunks with well developed buttress roots and furrowed barks yielded larger numbers of sandflies both in the rainy and less rainy seasons $(\mathrm{N}=10 ; \mathrm{x}=259.4)$, followed by simple trunks (cylindrical) with furrowed barks $(\mathrm{N}=6 ; \mathrm{x}=125.5)$, buttress roots with smooth barks $(\mathrm{N}=7 ; \mathrm{x}=41.7)$ and finally simple trunks with smooth barks $(\mathrm{N}=13 ; \mathrm{x}=25.8)$. Correlation tests of sandflies collected with suction traps and glass tubes (active searching technique) were significant both for trees that had buttress roots $(\mathrm{P}<0.05)$ with- 
out taking bark into account, and for simple trunks (cylindrical) with furrowed bark $(\mathrm{P}<0.001)$. However when correlating the sandflies collected on trees with buttress roots and furrowed bark the correlation found was highly significant $(\mathrm{P}<0.001)$. No correlation was found between the abundance of sandflies species and tree trunk diameters $(\mathrm{P}>0.05)$.

\section{DISCUSSION}

According to Lainson (1983), the sandflies in the Amazon region show strictly non-domestic habits, and according to our observations they distribute themselves in a continuous or discontinuous manner according to the ecological trend of the species. The behavioural variations of these sandflies are remarkable among species from one place to another and efforts to generalize their habitats are almost impossible (Forattini 1973). Therefore the study of their microdistribution in the forest is of major importance.

Among the trees species sampled for sandflies in our study area, five trees belonged to Mimosaceae family, three to the Apocynaceae, two to the Caesalpiniaceae, Lecythidaceae and Humiriaceae, while the others represented single species of Anacardiaceae, Anonaceae, Moraceae, Burseraceae, Elaeocarpaceae, Sapotaceae and Rubiaceae families. Most of these families (with the exception of Humiriaceae, Anacardiaceae, Elaeocarpaceae and Rubiaceae families) showed the largest number of species and individuals in the plateau plant community in DRF (Rodríguez 1995).

Morphological characteristics of some tree trunks that could be influencing the choice of resting places and sandfly distribution in primary forests of higher topographical elevation areas, have given rise to different opinions regarding the importance of these parameters. In our study area, tree trunks that showed well developed buttress roots and furrowed barks were influential in the choice of resting places, specifically of $L u$. umbratilis. Christensen and Vasquez (1982) using both battery-operated and mouth-operated aspirators, collected 52,033 individuals belonging to 33 sandfly species in tree trunks with buttress roots in primary forest areas in Panama and stated that these microhabitats are stable (regarding meteorological factors) presenting a great diversity and larger numbers of sandflies, which use these sites as diurnal resting places. Unfortunately the authors neither reported the number nor species of trees which were searched for sandflies, which prevent us from comparing their results with those obtained in the present study. Ready et al. (1986) studied $L u$. umbratilis ecology in a primary rain forest area in the State of Pará, Brazil, and pointed out that the choice of diurnal resting places in tree trunks by these dipterans was neither associated with classes of trunks (cylindrical with buttress root and fluted; $\mathrm{C}^{2}=2.3, \mathrm{P}>0.5$ ) nor the kind of bark (smooth and furrowed; $c^{2}=1.2, P>0.5$ ), except where bark was flaking off in large pieces. Barrett et al. (1991) in order to characterize natural shelters of $L u$. umbratilis in an area of primary forest of higher topographical elevation in the Balbina, Amazonas Region, found greater numbers of individuals on furrowed bark, wrinkled or with crevices or termitarium tree trunks $(\mathrm{x}=3.6 ; \mathrm{N}=17)$ than on those with smooth bark $(\mathrm{x}=0.08 ; \mathrm{N}=13)$.

Also tree trunk diameters, a variable which according to Ready et al. (1986) would be related to the choice of tree trunks as a resting place, could not be confirmed as a determinant of abundance, neither in the present study $(\mathrm{P}>0.05$ both with $\mathrm{CDC}$ trap and glass tube) nor that of Barrett et al. (1991). It is probable that results differ because of different samples sizes [ $\mathrm{N}=144$ in Ready et al. (1986); $\mathrm{N}=30$ in Barrett et al. (1991) and $\mathrm{N}=36$ (in the present study)], the use of different collection techniques [suction and sticky traps used by Ready et al. (1986); glass tubes by Barrrett et al. (1991); and suction traps and glass tubes used in this present study], different collecting seasons and time periods [rainy season by Ready et al. (1986); drier season by Barrett et al. (1991) and seasons of heavy and light rainfall in the present study].

French researchers pointed out that tree structure, nature and position in relation to the edge of the forest should determine the longitudinal sandfly distribution. However, Geoffroy et al. (1986) stated in addition that some tree species seem to be favoured by sandflies as resting, blood feeding and maintenance places, or as a support for the development of immature stages.

The tree species $D$. excelsa, $C$. villosum, E. amazonicus, $C$. amazonicum and $C$. longipedicelata were used by $65.3 \%$ of the collected sandflies as diurnal resting places. These trees show certain common characteristics: tall trunks, buttress roots and furrowed barks. Buttress roots are frequent in some large tree species occurring on soils offering a poor carrying capacity substrate [soil characteristic in plateau areas studied by Rodriguez (1995) at DFR] or have poorly developed open roots and are subject to wind gusts (Henwood 1973). Richards (1966) also stated that the trend to produce buttress roots has heritable and environment components.

According to Rodríguez (1995), D. excelsa accounts for $20 \%$ of the dominance [in the silvicultural sense, see Beard (1944)] and contributed to $9.9 \%$ of the canopy in a plateau plant commu- 
nity in DFR. Caryocar glabrum (C. villosum, species of the same genus, researched in this present study), A. spruceanum and Couratari cf. guianensis (C. longipedicelata, explanation similar to the latter), were also important in their role of dominance.

Other tree species with simple (cylindrical) trunk but with furrowed bark, such as $E$. atropetiolata and $P$. multijuga belonging to families Lecythidaceae and Mimosaceae, contributed $5.9 \%$ and $20.5 \%$ of the total relative dominance in this plateau plant community, and these also sheltered large numbers of sandflies (14.6\% of the total collected).

The presence of sandflies on any tree is not related to the tree family, but rather to the tree species, at least seasonally (Figs 1, 2, Table III) and there is a general trend for the grouping of the most and the least abundant sandfly species on the same trees, which was also observed by Chaniotis et al. (1972) (Panama), Geoffroy et al. (1986) (French Guyana) and by Ready et al. (1986) (Pará, Brazil).

Rutledge and Ellenwood (1975) stated that several tree species have different effects on the microenviroment in terms of shading, rain protection and composition, quantity and physical properties of the organic detritus. Factors such as floristic structure type, ground topography and tree morphologies, influence the forest microclimate as well as the frequency and distribution of sandfly populations in primary rain forest (Scorza \& Ortiz 1960, Rutledge et al. 1976, Le Pont \& Pajot 1980).

Therefore, it may be inferred that distribution throughout the year of the three most abundant sandfly species ( $\mathrm{Lu}$. umbratilis, $\mathrm{Lu}$. dendrophila and Lu. shannoni) in the plateau area of our study might be influenced by tree species. However, further studies with larger numbers of trees, taking into account the characteristics pointed out by this study and assembled in relation to tree species, should help to test further this hypotheses. They would also be helpful for a better understanding of cutaneous leishmaniasis epidemiology caused by Le. $(V$.) guyanensis, mainly with respect to the behaviour of the major vector, $L u$. umbratilis. Such detailed studies should help map the probable distribution patterns of this dipteran over plateau areas in the Brazilian Central Amazon.

\section{ACKNOWLEDGMENTS}

To Mr JC Hurtado Guerrero for help with the statistical data analysis and Dr B Robertson for the English revision.

\section{REFERENCES}

Barrett T, Freitas R, Naiff FM, Naiff RD 1991. A leishmaniose e seus transmissores em relação à saúde na Amazônia, p. 105-117. In AL Val, R Figliolo \& E Feldberg (eds), Bases Científicas para Estratégias de Preservação e Desenvolvimento da Amazônia. Fatos e perspectivas, Editora Manaus, Amazonas.

Barrett T, Freitas RA, Albuquerque MIC, Guerrero JHC 1996. Report on a collection of Lutzomyia sandflies (Diptera:Psychodidae) from the middle Solimões (Amazonas, Brazil). Mem Inst Oswaldo Cruz 91: 2735.

Beard JS 1944. Climax vegetation in tropical America. Ecology 25: 127-157.

Cabanillas MRS, Castellón EGB, Alencar MO de 1995. Estudo sobre abrigos naturais dos flebotomíneos (Diptera : Psychodidae) na Reserva Florestal Ducke Manaus, AM, Brasil. Bol Dir Nac Malariol y San Amb XXXV: 63-75.

Chaniotis BN, Tesh R, Correa MA, Johnson K 1972. Diurnal resting sites of Phlebotomine sandflies in a Panamanian tropical forest. J Med Entomol 9: 9198.

Christensen HÁ, Vasquez AM 1982. The tree-buttress biotope: A pathobiocenose of Leishmania braziliensis. Am J Trop Med Hyg 31: 243-251.

Christensen HÁ, Fairchild GB, Herrer Á, Johnson K, Young DG, Vaquez A 1983. The ecology of cutaneous leishmaniasis in the Republic of Panama. J Med Entomol 20: 463-484.

Forattini OP 1973. Entomologia Médica. IV Psychodidae, Phlebotominae, Leishmanioses, Bartonelloses, Edgar Blucher, São Paulo, 658 pp.

Franken W, Leopoldo PR, Matsule R, Ribeiro MN 1992. Estudo de intercepção da água de chuva em cobertura florestal amazônica do tipo terra firme. Acta Amazonica 12: 327-331.

Gentry A 1992. Tropical forest biodiversity: distributional patterns and their conservational significance. Oikos 63: 19-28.

Geoffroy B, Dedet JP, Lebbe J, Esterre P, Trape JF 1986. Notes sur les relation des vecteurs de leishmaniose avec les essences forestiéres en Guyane Francaise. Ann Par Hum Comp 61: 483-490.

Henwood K 1973. A structural model of forces in buttressed tropical rain forest trees. Biotropica 5: 83-93.

Lainson R 1983. The American leishmaniasis: some observations on their ecology and epidemiology. Trans R Soc Trop Med Hyg 77: 569-596.

Le Pont F, Pajot FX 1980. La leishmaniose en Guyane Francaise. I. Estude de 1' ecologie et du taux d'infection naturelle du vecteur Lutzomyia (Nyssomyia) umbratilis Ward et Fraiha 1977 en saison sèche. Considérations épidémiologiques. Cah ORSTOM sér Ent Méd et Parasitol 28: 359-382.

Penny N, Arias JR 1982. Insects of an Amazon Forest, Columbia University Press, New York, 289 pp.

Ready PD, Arias JR, Freitas RA 1985. A pilot study to control Lutzomyia umbratilis (Diptera: Psychodidae), the major vector of Leishmania braziliensis guyanensis in a peri-urban rain forest of Manaus, Amazonas State, Brazil. Mem Inst Oswaldo Cruz 80: 27-36.

Ready PD, Lainson R, Shaw JJ 1983. Leishmaniasis in Brazil XX. Prevalence of a enzootic rodent leishmaniasis (Leishmania mexicana amazonensis), and apparent absence of pian bois (L. braziliensis guyanensis) in plantation of introduced tree species 
and in other non climax forest in eastern Amazonia. Trans $R$ Soc Trop Med Hyg 77: 775-785.

Ready PD, Lainson R, Shaw JJ 1984. Habitat and seasonality of Psychodopygus wellcomei help incriminate it as a vector in Amazonia and Northeast Brazil. Trans $R$ Soc Trop Med Hyg 78: 543-544.

Ready PD, Lainson R, Shaw JJ, Ward R 1986. The ecology of Lutzomyia umbratilis Ward \& Fraiha (Diptera:Psychodidae) the major vector to man of Leishmania braziliensis guyanensis in north-eastern Amazonian Brazil. Bull Ent Res 76: 21-40.

Richards PW 1966. The Tropical Rain Forest. An Ecological Study, University Press, Cambridge, 450 pp.

Rodríguez JCT 1995. Aspectos Fitossociológicos das Comunidades Vegetais de uma Topossequência da Reserva Florestal Ducke do INPA, PhD Thesis, Convênio PGBTRN-INPA, Universidade do Amazonas, 335 pp.

Rutledge LC, Ellenwood DA 1975. Production of Phlebotomine sandflies on the open forest floor in
Panama: The species complement. Env Entomol 4: 71-77.

Rutledge LC, Walton BC, Ellenwood DA 1976. A transect study of sand fly populations in Panama (Diptera, Psychodidae). Env Entomol 5: 1149-1154.

Scorza JV, Ortiz I 1960. On microclimatic conditions of the habitats of certain sandfly species (Diptera: Psychodidae) from Venezuela. Zscrb Tropenmed $u$ Parasit ii: 433-440.

Shaw JJ, Lainson R, Ward R 1972. Leishmaniasis in Brazil. IV. Observations on the seasonal variations of Lutzomyia flaviscutellata in different types of forest and its relationship to enzootic rodent leishmaniasis Leishmania mexicana amazonensis. Trans $R$ Soc Trop Med Hyg 66: 709-717.

Smith A 1972. Buttressing of tropical trees: A descriptive model and new hypotheses. Amer Naturalist 106: 32-45.

Zar JH 1984. Biostatistical Analysis, Prentice-Hall Inc., New Jersey, 662 pp. 